\title{
Fear of COVID-19 and the Media Influence on Herbal Medication Use in Uganda: A Cross-Sectional Study
}

\author{
Phillip Musoke (D) \\ Brandy Nantaayi (D) \\ Rodney Kato Ndawula' \\ Babrah Wannyana (iD) ${ }^{2}$ \\ Nelson Ssewante $\mathbb{D}^{\prime}$ \\ Godfrey Wekha (D' \\ Ronald Olum (D) \\ Lourita Nakyagaba (D) \\ Dianah Rhoda Nassozi ${ }^{3}$ \\ Germinah Nabukeera ${ }^{4}$ \\ Andrew Marvin Kanyike (D) 5 \\ Daniel Ojilong (D) ${ }^{5}$ \\ Gabriel Madut Akech (1D ${ }^{5}$ \\ Jonathan Kajjimu (D) ${ }^{6}$ \\ Joshua Kiwumulo ${ }^{7}$ \\ Drake Agira $^{7}$ \\ Jerom Okot (iD ${ }^{7}$ \\ Felix Bongomin (D) ${ }^{1,8}$ \\ 'School of Medicine, College of Health \\ Sciences, Makerere University, Kampala, \\ Uganda; ${ }^{2}$ School of Clinical Medicine and \\ Dentistry, Kampala International \\ University Western Campus, Bushenyi, \\ Uganda; ${ }^{3}$ School of Health Sciences, \\ College of Health Sciences, Makerere \\ University, Kampala, Uganda; ${ }^{4}$ School of \\ Medicine, Kabale University, Kabale, \\ Uganda; ${ }^{5}$ Faculty of Health Sciences, \\ Busitema University, Mbale, Uganda; \\ ${ }^{6}$ Faculty of Medicine, Mbarara University \\ of Science and Technology, Mbarara, \\ Uganda; ${ }^{7}$ Faculty of Medicine, Gulu \\ University, Gulu, Uganda; ${ }^{8}$ Department of \\ Medical Microbiology and Immunology, \\ Faculty of Medicine, Gulu University, \\ Gulu, Uganda
}

Correspondence: Felix Bongomin Department of Medical Microbiology and Immunology, Faculty of Medicine, Gulu University, P. O. Box, 166, Gulu, Uganda Email drbongomin@gmail.com
Background: The coronavirus disease-2019 (COVID-19) pandemic has created fear in people around the world. This has led to the widespread use of various herbal remedies in its prevention and treatment regardless of the paucity of scientific evidence about their safety and efficacy. This study assessed the fear of COVID-19 and the influence of media on the use of herbal medicine to prevent or treat COVID-19 in Uganda.

Methods: In the first 2 weeks of July 2021, a descriptive online cross-sectional study was carried out anonymously in the general population in Uganda. A validated questionnaire was used to collect data on herbal medicine use and the influence of media. Fear of COVID-19 was rated using the Fear of COVID-19 Scale (FCV-19S).

Results: We recruited 488 participants, 273 (55.9\%) were female, with a median age of 25 (range: 18-73) years. Sixty-seven (57.8\%) participants had a confirmed COVID-19 diagnosis. The mean FCV-19S score was 21.7 SD 5.9 with $53.3 \%$ reporting high levels of COVID-19 fear. About 57.4\% of participants reported using herbal remedies either to prevent or treat COVID-19-like symptoms. Media was the main source of information, with more than $80 \%$ of the participants reporting seeing or accessing information about herbal medication use. Women (adjusted odds ratio (aOR): 1.74, 95\% CI: 1.2-2.5, $\mathrm{p}=0.003$ ) and people with a previously confirmed COVID-19 diagnosis (aOR: 3.1, 95\% CI: 1.35-7.14, $\mathrm{p}=0.008$ ) had a statistically significantly higher FCV-19S score. Being unemployed (aOR: 1.0, 95\% CI: $1.1-2.3, \mathrm{p}=0.008$ ) and a female (aOR: 1.0, 95\% CI: 1.1-2.3, p=0.012) were statistically significantly associated with herbal medicine use. Participants who used herbal remedies had a higher median FCV-19S score compared to non-users (23 versus 21, $\mathrm{p}<0.001)$.

Conclusion: The use of herbal medicines to treat or prevent COVID-19 is a widespread practice among the general population in Uganda amidst the high levels of fear of COVID-19.

Keywords: COVID-19, fear, media, herbal medicine, health awareness, Uganda

\section{Introduction}

The coronavirus disease-2019 (COVID-19) pandemic has affected over 190 million people with over 4.2 million deaths worldwide at the time of writing. ${ }^{1}$ Uganda has so far suffered two waves of COVID-19 with the most recent associated with a highly infectious strain leading to over 93,000 cases and 2690 deaths as of 1st August 2021.

Globally, about $80 \%$ of the population is estimated to rely on herbal medicines for disease prevention and as alternative/complementary medicine. ${ }^{2}$ Some of these have been approved and/or recommended for use by health professionals in the 
prevention and treatment of diseases including COVID-19. For example, in Uganda, the National Drug Authority approved the use of COVIDEX a locally made herbal remedy as a supportive drug treatment for COVID-19. ${ }^{3}$ Due to the widespread use of herbal medicines, it has been suggested that policymakers emphasize education initiatives aimed at improving public awareness of herbal medicines use in disease prevention and treatment. ${ }^{4}$ Despite being readily available, herbal remedies are not without toxicities, and therefore, to ensure the safety of patients, their use must be evidence-based as supported by toxicology studies. ${ }^{2,4}$ Media has been a major portal through which information dissemination has occurred since the pronunciation of the COVID-19 pandemic though it has also served as a channel for misinformation to the general population. ${ }^{5,6}$ This includes information on herbal medicines use to address an array of COVID-19 symptoms. ${ }^{4}$ However, the downside is that adverse effects profiles of these herbal remedies are yet to be scientifically determined. $^{2}$

The COVID-19 pandemic has led to profound psychological effects among people across the world including fear. Fear is defined as an unpleasant emotional state that is triggered by the perception of threatening stimuli. ${ }^{7}$ For example, in a recent study conducted in Canada, one-third of participants were found to be concerned about COVID19. ${ }^{8}$ Similarly, studies conducted in Germany and the US reported the same concern. ${ }^{9,10}$ This fear has in itself contributed to the high mortality through suicide as noted in series of reports in different countries. ${ }^{11,12}$

Unfortunately, there is a paucity of information on fear of COVID-19 and the influence of media on herbal medicines use in Uganda. Therefore, this study aimed to close this gap.

\section{Methods}

\section{Study Design}

In the first 2 weeks of July 2021, an online descriptive, cross-sectional study was conducted anonymously in the general population in Uganda.

\section{Study Population}

Eligible participants were those aged 18 years and above, able to access smartphones, and were within the social media channels namely WhatsApp Messenger and Facebook Inc. California, USA, or Telegram were included in the study. The participants were excluded if they were not in any social media channels or could not access the internet. We had intended to perform a community-based national sampling survey, but it was not feasible due to the ongoing pandemic and lockdown measures to prevent the spread of COVID-19. Therefore, the data was collected via an online KoBo Toolbox, which included an electronic informed consent form on the first page. It was also made clear that participation in this study was entirely voluntary. Participants were then asked to complete the questionnaire.

\section{Sample Size Calculation and Sampling}

The sample size was calculated using Epi Info StatCalc for infinite population surveys. With a 5\% acceptable margin of error, design effect of 1.0, cluster effect of 1.0, and a power of $80 \%$, the estimated sample size at $95 \%$ confidence interval was 384 participants. To cater for non-response associated with online surveys, $30 \%$ of the estimated sample size was added leading to a final sample size of 499 participants.

\section{Questionnaire Development}

The questionnaire was divided into three sections: Sociodemographic characteristics (age, sex, tribe, religion, residence, level of education, employment status, and job), Questions on Fear of COVID-19, and the impact of media on public awareness concerning the use of natural remedies against COVID-19.

\section{Measurements \\ Fear of COVID-19}

It was assessed using seven ${ }^{7}$ items obtained from the fear of COVID-19 scale (FCV-19S) ${ }^{13}$ which is a reliable and validated tool in assessing fear of COVID-19 among the general population and is also useful in allaying COVID19 fears among individuals. The participants indicated their level of agreement with the statements using a fiveitem Likert-type scale. Answers included "strongly disagree", "disagree", "neutral", "agree", and "strongly agree". The minimum score possible for each question is 1 , and the maximum is $5((1=$ strongly disagree; $5=$ strongly agree)). A total score was then calculated by adding up each item score (ranged from 7 to 35). A higher level of fear toward COVID-19 is indicated by the higher FCV-19S score. The mean FCV-19 score was used to define low ( $<$ mean) and high $(\geq$ mean) levels of fear of COVID-19. In our study population, Cronbach's alpha for the response to FCV-19S was 0.87 , indicating excellent internal reliability of this scale. 


\section{Herbal Medical Use}

This was assessed by asking the participants to report their use of herbal remedies either to prevent or treat COVID19-like symptoms themselves.

\section{The Impact of Media on Public Awareness Concerning the Use of Natural Remedies Against COVID-19}

A validated 5-item tool ${ }^{14}$ was used to evaluate the influence of media on herbal medicines use in the general population during the COVID-19 pandemic. The first question asked the participants if they have accessed media awareness messages correcting the misinformation about using natural remedies (herbs and food supplements) as preventive medicine. The next two questions (2nd and 3rd) asked them about the sources of those media messages and how they accessed them. The fourth question asked them how these messages affected their level of awareness concerning the use of natural remedies to fight COVID-19. The final question in this section was to evaluate the behavioral changes of the participants who watched the awareness messages by asking them which of the listed items (most common herbs and protective measures) they had stopped as a result of the awareness messages.

\section{Data Analysis and Management}

Fully completed questionnaires were extracted from KoBo Toolbox and exported to a Microsoft Excel 2016 for cleaning and coding. The cleaned data was exported to STATA 16 (StataCorp LLC, College Station, Texas, USA) for analysis. Numerical data were then summarized as means and standard deviations or median and range as appropriate. Categorical variables were summarized as frequencies and relative percentages. To assess the association between independent variables with fear of COVID-19 and herbal medicine use, chi-square test or Fishers' exact test (for categorical variables) and Mann-Whitney $U$-test (for continuous variables) were used at bivariate analysis. All independent variables with $\mathrm{p}<0.2$ at bivariate analysis were included in the stepwise multivariable logistic regression models to adjust for confounders. A $\mathrm{p}<0.05$ was considered statistically significant.

\section{Ethics}

The study was performed according to the Declaration of Helsinki, after obtaining approval from Mulago Hospital
Research and Ethics Committee (Approval number MHREC 2097).

\section{COVID-19 Safety Precautions}

The study was conducted following the Ministry of Health and the National COVID-19 task force guidelines of Uganda. All the study team meetings, training, recruitment, data collection, and manuscript drafting were conducted online.

\section{Results}

\section{Characteristics of the Participants}

We recruited 488 participants, 273 (55.9\%) were female, with a median age of 25 (range: 18-73) years. The majority of the participants were from central Uganda $(62.5 \%$, $\mathrm{n}=305)$ and had attained tertiary education $(89.0 \%$, $\mathrm{n}=436)$. More than half were unemployed $(56.6 \%)$ and over one-third were Catholics (34.8\%). The majority (75.8\%) of the participants self-reported to have ever suffered from COVID-19, however, only $57.8 \%$ were microbiologically confirmed COVID-19 cases. The majority had one or more relatives who suffered from COVID19 (89.9\%). Table 1 summarizes the socio-demographic characteristics of the participants.

\section{Fear of COVID-19}

The mean FCV-19S score was 21.7 SD 5.9. Of the 488 participants, $260(53.3 \%)$ had a high level of fear. At bivariate analysis, fear of COVID-19 was significantly associated with: being male $(p=0.003)$, employment $(\mathrm{p}=0.006)$, being Anglican $(\mathrm{p}=0.022)$, previously confirmed diagnosis of COVID-19 ( $\mathrm{p}=0.005)$, and having had any chronic illness $(p=0.024)$. Table 2 summarizes factors associated with fear of COVID-19. At multivariable analysis, predictors of fear of COVID-19 were: being female (adjusted odds ratio: 1.74, 95\% CI: 1.2-2.5, $\mathrm{p}=0.003$ ) and previously confirmed diagnosis of COVID19 (aOR: 3.1, 95\% CI: 1.35-7.14, p=0.008) (Table 3).

\section{Herbal Medical Use}

Of the 488 participants, 280 (57.4\%) reported using herbal remedies for either prevention $(46.7 \%, \mathrm{n}=228)$ or treatment for COVID-19-like symptoms $(46.3 \%, \mathrm{n}=222)$ or both $(34.8 \%, \mathrm{n}=170)$ (Figure 1). Ginger was the most used natural remedy for prevention $(40.7 \%, \mathrm{n}=88)$ and treatment $(36.6 \%, \mathrm{n}=74)$, followed by lemon, prevention $(40.3 \%, n=87)$ and treatment $(33.7 \%, 68)$. Other used 
Table I Socio-Demographic Characteristics of Participants

\begin{tabular}{|c|c|c|}
\hline Variable & Frequency & Percentage \\
\hline Age, median(range), years & 24 & $18-73$ \\
\hline$<25$ & 245 & 50.2 \\
\hline$\geq 25$ & 243 & 49.8 \\
\hline \multicolumn{3}{|l|}{ Sex } \\
\hline Male & 273 & 55.9 \\
\hline Female & 215 & 44.1 \\
\hline \multicolumn{3}{|l|}{ Region of residence } \\
\hline Central & 305 & 62.5 \\
\hline East & 56 & $\mathrm{II} .5$ \\
\hline West & 34 & 6.97 \\
\hline North & 93 & 19.1 \\
\hline \multicolumn{3}{|l|}{ Highest level of education } \\
\hline Secondary & 45 & 9.2 \\
\hline Tertiary & 436 & 89.3 \\
\hline None & 7 & 1.3 \\
\hline \multicolumn{3}{|l|}{ Employment status } \\
\hline Employed & 212 & 43.4 \\
\hline Not employed & 276 & 56.6 \\
\hline \multicolumn{3}{|l|}{ Religion } \\
\hline Anglican & 152 & 31.2 \\
\hline Born again & 51 & 10.5 \\
\hline Catholic & 170 & 34.8 \\
\hline Islam & 52 & 10.7 \\
\hline Pentecostal & 28 & 5.7 \\
\hline Seventh days Adventist & 24 & 4.9 \\
\hline Others & 11 & 2.3 \\
\hline \multicolumn{3}{|l|}{ Ever suffered of COVID-I9 } \\
\hline Yes & 118 & 24.2 \\
\hline No & 370 & 75.8 \\
\hline \multicolumn{3}{|l|}{$\begin{array}{l}\text { If yes, confirmed medically } \\
(n=\mid 16)\end{array}$} \\
\hline Yes & 67 & 57.8 \\
\hline No & 49 & 42.2 \\
\hline \multicolumn{3}{|l|}{ Relative suffered from COVID-19 } \\
\hline Yes & 439 & 89.9 \\
\hline No & 49 & 10.1 \\
\hline \multicolumn{3}{|l|}{ Any chronic illness } \\
\hline Yes & 30 & 6.2 \\
\hline No & 458 & 93.9 \\
\hline
\end{tabular}

natural remedies were; COVIDEX (a recently approved herbal medicine drug for use in the Uganda), prevention $(10.6 \%, \mathrm{n}=23)$ and treatment $(12.4 \%, \mathrm{n}=25)$ and steaming, prevention $(12 \%, \mathrm{n}=26)$ and treatment $21(10.4 \%, \mathrm{n}=21)$.
Table 4 summarizes the herbal medicines (natural remedies) used for the prevention and treatment of COVID-19. At bivariate analysis, fear of COVID-19 was significantly linked with: being male $(\mathrm{p}=0.013)$, employed $(\mathrm{p}=0.01)$, having a relative who suffered from COVID-19 $(p=0.034)$, high level of fear of COVID-19 $(p<0.0001)$, and having had any chronic illness $(p=0.012)$, Table 5 summarizes factors associated with herbal medicine use among the participants. At binary logistic regression, factors independently associated with herbal medication use were: being female (aOR: 1.59, 95\% CI: 1.11-2.33, $\mathrm{p}=0.012$ ) and being unemployed (aOR: 1.64, 95\% CI: 1.15-2.38, $\mathrm{p}=0.008$ ), (Table 6) Participants who used herbal remedies had a high median FCV-19S score compared to non-users (23 versus 21, $\mathrm{p}<0.001$ ) (Figure 2).

\section{The Impact of Media on Public Awareness Concerning the Use of Natural Remedies Against COVID-19}

Media is the main source of information from which more than $80 \%$ of the participants reported to have seen or accessed messages about herbal medication use. Media further increased the use of herbal medication in $65 \%$ of the participants. Most of the media messages watched by our participants were sourced from the Uganda Ministry of Health $(39.9 \%, n=157)$, followed by the WHO $(28.1 \%, n=111)$.

\section{Discussion}

In the current study, more than half of the participants reported using herbal remedies for the prevention and treatment of COVID-19. Media was the main source of information about herbal medication use. Almost half of the participants self-reported high levels of fear of COVID-19.

Our findings were consistent with a similar study in Vietnam where nearly half of the participants were found to use herbal medicines for the treatment of COVID-19. ${ }^{15}$ However, in Saudi Arabia use of herbal medicines was way higher (92.7\%) during this COVID-19 pandemic. ${ }^{16}$ In our study, female participants as well as the unemployed were found to be more likely to use herbal medicines. This finding is, however, contrary to that of Vietnam where low-income earners were less likely to use herbal medicines. This can be explained in part by the fact that herbal remedies in Uganda are cheap and easily accessible. 
Table 2 Bivariate Analysis for Socio-Demographic Factors Associated with Level of Fear of COVID-19

\begin{tabular}{|c|c|c|c|c|}
\hline \multirow[t]{2}{*}{ Variable } & \multicolumn{3}{|c|}{ Level of Fear of COVID-I9 } & \multirow[b]{2}{*}{ P-value } \\
\hline & $\begin{array}{c}\text { ALL }(n=488) \\
\text { Freq }(\%)\end{array}$ & $\begin{array}{c}\text { Low Level }(n=228) \\
\text { Freq }(\%)\end{array}$ & $\begin{array}{c}\text { High Level }(n=260) \\
\text { Freq (\%) }\end{array}$ & \\
\hline $\begin{array}{l}\text { Age, median(range), years } \\
<25 \\
\geq 25\end{array}$ & $\begin{array}{l}24(18-73) \\
245(50.2) \\
243(49.8)\end{array}$ & $\begin{array}{l}24(18-64) \\
115(50.4) \\
113(49.6)\end{array}$ & $\begin{array}{l}25(18-73) \\
130(50) \\
130(50)\end{array}$ & $\begin{array}{c}0.3271 \\
0.928\end{array}$ \\
\hline $\begin{array}{l}\text { Sex } \\
\text { Male } \\
\text { Female }\end{array}$ & $\begin{array}{l}273(56.0) \\
215(44.1)\end{array}$ & $\begin{array}{l}144(63.2) \\
84(36.8)\end{array}$ & $\begin{array}{l}\text { I29 (49.6) } \\
\text { I3I (50.4) }\end{array}$ & 0.003 \\
\hline $\begin{array}{l}\text { Region of residence } \\
\text { Central } \\
\text { East } \\
\text { West } \\
\text { North }\end{array}$ & $\begin{array}{l}305(62.5) \\
56(11.5) \\
93(19.1) \\
34(7.0)\end{array}$ & $\begin{array}{l}148(64.9) \\
24(10.5) \\
41(28) \\
15(6.6)\end{array}$ & $\begin{array}{l}157(60.4) \\
32(12.3) \\
52(20) \\
19(7.3)\end{array}$ & 0.780 \\
\hline $\begin{array}{l}\text { Highest level of education } \\
\text { Secondary } \\
\text { Tertiary } \\
\text { None }\end{array}$ & $\begin{array}{c}45(9.22) \\
436(89.34) \\
7(1.25)\end{array}$ & $\begin{aligned} 25 & (1 \mathrm{I}) \\
20 \mathrm{I}(88.2) & \\
2 & (0.1)\end{aligned}$ & $\begin{aligned} 20 & (7.7) \\
235 & (90.4) \\
5 & (1.9)\end{aligned}$ & 0.156 \\
\hline $\begin{array}{l}\text { Employment status } \\
\text { Employed } \\
\text { Not employed }\end{array}$ & $\begin{array}{l}212(43.44) \\
276(56.56)\end{array}$ & $\begin{array}{l}84(36.8) \\
144(63.2)\end{array}$ & $\begin{array}{l}\text { I } 28(49.2) \\
132(50.8)\end{array}$ & 0.006 \\
\hline $\begin{array}{l}\text { Religion } \\
\text { Anglican } \\
\text { Born again } \\
\text { Catholic } \\
\text { Islam } \\
\text { Pentecostal } \\
\text { Seventh days Adventist } \\
\text { Others }\end{array}$ & $\begin{array}{c}\text { I52 (3I.2) } \\
5 \text { I (I0.5) } \\
\text { I70 (34.8) } \\
52(10.7) \\
28(5.7) \\
24(4.9) \\
\text { II (2.3) }\end{array}$ & $\begin{array}{c}68(29.8) \\
33(14.5) \\
76(33.3) \\
17(7.5) \\
15(6.6) \\
11(4.8) \\
8(3.5)\end{array}$ & $\begin{array}{c}84(32.3) \\
18(6.9) \\
94(36.4) \\
35(13.5) \\
13(5) \\
13(5) \\
3(1.2)\end{array}$ & 0.022 \\
\hline $\begin{array}{l}\text { Ever suffered from COVID-I9 } \\
\text { Yes } \\
\text { No }\end{array}$ & $\begin{array}{l}118(24.2) \\
370(75.8)\end{array}$ & $\begin{array}{l}54(23.7) \\
174(76.3)\end{array}$ & $\begin{array}{c}64(24.6) \\
196(75.4)\end{array}$ & 0.833 \\
\hline $\begin{array}{l}\text { If yes, Confirmed by medical test } \\
(\mathbf{n}=|| 6) \\
\text { Yes } \\
\text { No }\end{array}$ & $\begin{array}{l}67(57.8) \\
49(42.2)\end{array}$ & $\begin{array}{l}(n=53) \\
23(43.4) \\
30(56.6)\end{array}$ & $\begin{array}{l}(n=63) \\
44(69.8) \\
19(30.2)\end{array}$ & 0.005 \\
\hline $\begin{array}{l}\text { Relative suffered from COVID-I9 } \\
\text { Yes } \\
\text { No }\end{array}$ & $\begin{array}{l}439(90) \\
49(10)\end{array}$ & $\begin{array}{c}209(91.7) \\
19(8.3)\end{array}$ & $\begin{array}{c}230(88.5) \\
30(11.5)\end{array}$ & 0.291 \\
\hline $\begin{array}{l}\text { Impact of media } \\
\text { I decreased the use } \\
\text { I increased the use } \\
\text { No effect }\end{array}$ & $\begin{array}{c}34(8.6) \\
176(44.7) \\
184(46.7)\end{array}$ & $\begin{array}{c}8(4.4) \\
64(35.4) \\
109(60.2)\end{array}$ & $\begin{array}{l}26(12.2) \\
112(52.6) \\
75(35.2)\end{array}$ & $<0.0001$ \\
\hline $\begin{array}{l}\text { Any chronic illness } \\
\text { Yes } \\
\text { No }\end{array}$ & $\begin{array}{c}30(6.2) \\
458(93.8)\end{array}$ & $\begin{array}{c}8(3.5) \\
220(96.5)\end{array}$ & $\begin{array}{c}22(8.5) \\
238(91.5)\end{array}$ & 0.024 \\
\hline
\end{tabular}


Table 3 A Multivariable Logistic Regression Showing Predictors of Fear of COVID-19

\begin{tabular}{|c|c|c|c|}
\hline Variable & $\begin{array}{c}\text { Adjusted } \\
\text { Odds Ratio }\end{array}$ & $95 \% \mathrm{Cl}$ & P-value \\
\hline \multicolumn{4}{|l|}{ Sex } \\
\hline Male & 1.0 & - & 0.003 \\
\hline Female & 1.74 & $1.21-2.50$ & \\
\hline \multicolumn{4}{|l|}{ Employment status } \\
\hline Employed & 1.0 & - & 0.158 \\
\hline Not employed & 1.77 & $0.80-3.93$ & \\
\hline \multicolumn{4}{|l|}{$\begin{array}{l}\text { Confirmed COVID- } \\
19(n=116)\end{array}$} \\
\hline Yes & 3.1 & $1.35-7.14$ & 0.008 \\
\hline No & 1.0 & - & \\
\hline \multicolumn{4}{|l|}{ Herbal medical use } \\
\hline Yes & 1.0 & & 0.755 \\
\hline No & 1.14 & $0.49-2.68$ & \\
\hline \multicolumn{4}{|l|}{ Any chronic illness } \\
\hline Yes & 1.0 & - & 0.198 \\
\hline No & 0.23 & $0.03-2.14$ & \\
\hline \multicolumn{4}{|l|}{ Religion } \\
\hline Anglican & 1.0 & - & \\
\hline Born again & 0.957 & $0.4-2.27$ & 0.920 \\
\hline Catholic & 2.167 & $0.8 \mathrm{I}-5.82$ & 0.125 \\
\hline Islam & 0.956 & $0.4 \mathrm{I}-2.25$ & 0.917 \\
\hline Pentecostal & 3.152 & $0.67-14.86$ & 0.147 \\
\hline Seventh days & 1.364 & $0.46-4.07$ & 0.578 \\
\hline \multicolumn{4}{|l|}{ Adventist } \\
\hline Others & 0.574 & $0.21-1.55$ & 0.272 \\
\hline
\end{tabular}

Additionally, low-income earners may not be able to afford the high costs of COVID-19 treatment hence opting for herbal remedies. Poor health-seeking behaviors and challenges associated with access to health facilities during the pandemic in Uganda are yet another fact that cannot be over-emphasized as this has been widely documented. $^{31}$

Our results as well as those of a study conducted in Saudi Arabia ${ }^{16}$ showed that media was the main source of information from which more than $80 \%$ of the participants reported to have seen or accessed messages about herbal medication use. Media further increased the use of herbal medication in $65 \%$ of the participants which is consistent with what studies by Alotiby et $\mathrm{al}^{14}$ and Alyami et $\mathrm{al}^{4}$ reported that the biggest motivators for participants to pursue herbal products were Media and the Internet. ${ }^{4,14}$ However, the majority of participants in our study reported that they would hold information from the Ministry of Health and WHO with high regard a finding consistent with that of Kwok et $\mathrm{al}^{29}$ and Alotiby et al. ${ }^{14}$ In this respect, policymakers and health workers could use this opportunity to disseminate the right information to the public regarding the safe use of herbal remedies. ${ }^{30}$

The current study revealed a mean FCV-19S score of 21.7 ( $\mathrm{SD}=5.9$, median=21). This was higher than reported in similar studies done in Eastern Europe (mean=17.2, median=17) and Japan (median=16.67) as well as in other countries like New Zealand, Spain, Russia, Israel, and Pakistan, where the mean scores were distributed between 15 and 19 points. $^{17-22}$ The second wave of COVID-19 in Uganda was associated with higher mortality and morbidity which could have sparked fear among the general population hence this relatively higher score since the study was conducted during this wave. The FCV-19S score was higher among females compared to males which is similar to other studies carried out among adults living in the United States, ${ }^{23}$ and others from Japan, Bangladesh, Greece, India, and China populations. ${ }^{18}$ This widespread finding could be explained among other factors by the fact that females show higher stress responsiveness than men. ${ }^{24}$ Fear of COVID-19 was also high among those with a previously confirmed COVID-19 diagnosis similar to a study carried out in Brazil. ${ }^{25}$ Similar to a report by Colizzi et $\mathrm{al}^{26}$ contracting COVID-19 increases fear and could even worsen anxiety and post-traumatic stress disorder. ${ }^{27}$ These findings continue to further underscore the importance of paying greater attention to the mental well-being of the general population in new COVID-19 waves, to curb the rising psychological impact of the COVID-19 pandemic. $^{28}$

\section{Limitations}

A number of limitations were taken into consideration as we interpreted these results. First, the study employed a non-random sample. Participation in the study was voluntary and no information was available about the characteristics of those who did not participate. Secondly, the cross-sectional design of our study does not allow for a causal interpretation of the results. 


\section{$\Sigma=488$}

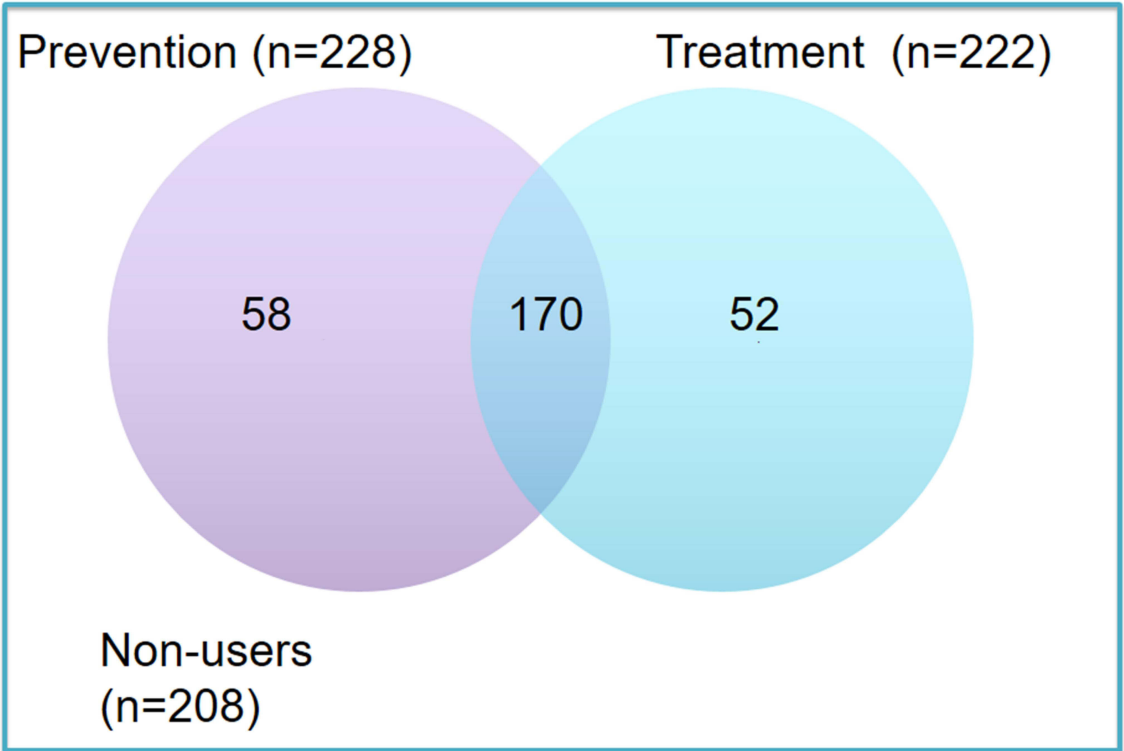

Figure I Herbal medical use to prevent or treat COVID-19.

Thirdly, due to the COVID-19 pandemic control measures, the study was conducted in a situation, where the country was in the second lockdown. The data collection was only possible via online methods hence missing out on the population that did not own smartphones, had poor connectivity to the internet, or could not meet the data costs for participating in this study. This could lead

Table 4 Herbal Medicines (Natural Remedies) Used for Prevention and Treatment of COVID-19

\begin{tabular}{|l|c|c|}
\hline Variable & $\begin{array}{c}\text { Prevention } \\
\text { (N=2 I6) } \mathbf{n} \text { (\%) }\end{array}$ & $\begin{array}{r}\text { Treatment } \\
\text { (N=202), n (\%) }\end{array}$ \\
\hline Ginger & $88(40.7)$ & $74(36.6)$ \\
Lemon & $87(40.3)$ & $68(33.7)$ \\
Garlic & $64(29.6)$ & $48(23.8)$ \\
Steaming & $26(12)$ & $21(10.4)$ \\
COVIDEX & $23(10.6)$ & $25(12.4)$ \\
Other concoctions & $14(6.5)$ & $5(2.5)$ \\
Mangoes & $12(5.6)$ & $3(1.5)$ \\
Eucalyptus & $12(5.6)$ & $9(4.5)$ \\
Onions & $10(4.6)$ & $9(4.5)$ \\
Avocado & $6(2.8)$ & $1(0.5)$ \\
Marijuana & $5(2.3)$ & $3(1.5)$ \\
Aloe vera & $4(1.9)$ & $2(1)$ \\
Guava & $4(1.9)$ & $2(1)$ \\
Mulondo & $1(0.5)$ & $0(0)$ \\
\hline
\end{tabular}

to selection bias as those with poor connectivity to the internet or those that could not meet the data costs might have been missed, this limits the generalization of these findings. Fourthly, since the questionnaire was self-administered, there was a possibility of obtaining correct answers without a full understanding of the questions, recall bias and participants may have interpreted the questions differently. We also did not consider the quantity of ginger or garlic consumed that would be regarded as herbal medicine in our study. However, despite these limitations, this is the first study in Uganda assessing the fear of COVID-19 and the impact of media on herbal medication use against COVID-19.

\section{Conclusion}

The use of herbal medicine during the COVID-19 pandemic is a widespread practice among the general population in Uganda amidst the high levels of fear of COVID-19. These findings may have implications for future medical research in Uganda, and policy-makers and those in the pharmaceutical industry concerning future regulations and product development. Continuous public health awareness is suggested on the different natural remedies and further studies on the role of herbal medicine in patient management are recommended. 
Table 5 Bivariate Analysis for Socio-Demographic Factors Associated Herbal Medical Use

\begin{tabular}{|c|c|c|c|c|}
\hline \multirow{2}{*}{ Variable } & \multirow{2}{*}{$\begin{array}{l}\text { All, }(n=488) \text { Freq } \\
(\%)\end{array}$} & \multicolumn{2}{|c|}{ Herbal Medical Use } & \multirow[t]{2}{*}{ P-value } \\
\hline & & $\begin{array}{l}\text { Yes (280) Freq } \\
(\%)\end{array}$ & $\begin{array}{l}\text { No }(n=208) \text { Freq } \\
(\%)\end{array}$ & \\
\hline Age, median(range), years & $24(18-73)$ & $24(18-73)$ & $25(18-64)$ & 0.620 \\
\hline$<25$ & $245(50.2)$ & $142(50.7)$ & $103(49.5)$ & 0.855 \\
\hline$\geq 25$ & $243(49.8)$ & $138(49.3)$ & $105(50.5)$ & \\
\hline \multicolumn{5}{|l|}{ Sex } \\
\hline Male & $273(55.9)$ & $\mid 43(5 \mid .7)$ & $130(62.5)$ & 0.013 \\
\hline Female & $215(44.1)$ & $137(49.3)$ & $78(37.5)$ & \\
\hline \multicolumn{5}{|l|}{ Region of residence } \\
\hline Central & $305(62.5)$ & $188(67.2)$ & $117(56.3)$ & 0.077 \\
\hline East & $56(11.5)$ & $30(10.7)$ & $26(12.5)$ & \\
\hline West & $93(19.1)$ & $47(16.7)$ & $46(22.1)$ & \\
\hline North & $34(6.9)$ & $15(5.4)$ & $19(9.1)$ & \\
\hline \multicolumn{5}{|l|}{ Highest level of education } \\
\hline Secondary & $45(9.2)$ & $30(10.7)$ & $15(7.2)$ & 0.451 \\
\hline Tertiary & $436(89.3)$ & $246(87.9)$ & $190(91.4)$ & \\
\hline Primary & $7(1.5)$ & $4(1.4)$ & $3(1.4)$ & \\
\hline \multicolumn{5}{|l|}{ Employment status } \\
\hline Employed & $212(43.4)$ & $136(48.6)$ & $76(36.5)$ & 0.010 \\
\hline Not employed & $276(56.6)$ & $\mid 44(5 \mid .4)$ & $132(63.5)$ & \\
\hline \multicolumn{5}{|l|}{ Religion } \\
\hline Anglican & $152(31.2)$ & $90(32.1)$ & $62(29.8)$ & 0.940 \\
\hline Born again & $5 I(10.5)$ & $28(10)$ & $23(I 1.1)$ & \\
\hline Catholic & $170(34.8)$ & $94(33.6)$ & $76(36.5)$ & \\
\hline Islam & $52(10.7)$ & $32(I 1.4)$ & 20(9.6) & \\
\hline Pentecostal & 28(5.7) & $17(6.1)$ & $\mathrm{II}(5.3)$ & \\
\hline Seventh days Adventist & $24(4.9)$ & $14(5)$ & $10(4.8)$ & \\
\hline Others & $\mathrm{II}(2.3)$ & $5(1.8)$ & $6(2.9)$ & \\
\hline \multicolumn{5}{|l|}{ Ever suffered from COVID-19 } \\
\hline Yes & $118(24.2)$ & $80(28.6)$ & $38(18.3)$ & 0.010 \\
\hline No & $370(75.8)$ & $200(71.4)$ & $170(81.7)$ & \\
\hline If yes, confirmed by medical test $(n=\mid 16)$ & & $(n=80)$ & $(n=36)$ & \\
\hline Yes & $67(57.7)$ & $44(55)$ & $23(63.9)$ & 0.420 \\
\hline No & $49(42.3)$ & $36(45)$ & $13(36.1)$ & \\
\hline \multicolumn{5}{|l|}{ Relative suffered from COVID-I9 } \\
\hline Yes & $439(89.9)$ & $259(92.5)$ & $180(86.5)$ & 0.034 \\
\hline No & $49(10.1)$ & $21(7.5)$ & $28(13.5)$ & \\
\hline \multicolumn{5}{|l|}{ Level of fear } \\
\hline High level & $260(53.3)$ & $|7|(6||)$. & $89(42.8)$ & $<0.0001$ \\
\hline Low level & $228(46.7)$ & $109(38.9)$ & $119(57.2)$ & \\
\hline \multirow{2}{*}{\multicolumn{5}{|c|}{$\begin{array}{l}\text { Media awareness message natural remedies against } \\
\text { COVID-19 }\end{array}$}} \\
\hline & & & & \\
\hline Yes & $394(80.7)$ & $230(82.1)$ & 164(78.9) & 0.417 \\
\hline No & $94(19.3)$ & $50(17.9)$ & $44(21.1)$ & \\
\hline
\end{tabular}

(Continued) 
Table 5 (Continued).

\begin{tabular}{|c|c|c|c|c|}
\hline \multirow[t]{2}{*}{ Variable } & \multirow{2}{*}{$\begin{array}{l}\text { All, }(n=488) \text { Freq } \\
(\%)\end{array}$} & \multicolumn{2}{|c|}{ Herbal Medical Use } & \multirow[t]{2}{*}{ P-value } \\
\hline & & $\begin{array}{l}\text { Yes (280) Freq } \\
(\%)\end{array}$ & $\begin{array}{l}\text { No }(n=208) \text { Freq } \\
(\%)\end{array}$ & \\
\hline \multicolumn{5}{|c|}{ Source of awareness message $(n=394)$} \\
\hline WHO & III (28.I) & $56(24.4)$ & $55(33.5)$ & 0.026 \\
\hline $\mathrm{MOH}$ & $157(39.9)$ & $89(38.7)$ & $68(41.5)$ & \\
\hline Others & $126(32)$ & $85(37)$ & $4 I(25)$ & \\
\hline \multicolumn{5}{|c|}{$\begin{array}{l}\text { Effect of these media messages on use of natural remedies } \\
(n=394)\end{array}$} \\
\hline I decreased the use & $34(8.6)$ & $22(9.6)$ & $12(7.3)$ & $<0.0001$ \\
\hline I increased the use & I76(44.8) & I33(57.8) & $43(26.2)$ & \\
\hline No effect & 184(46.7) & $75(32.6)$ & $109(66.5)$ & \\
\hline \multicolumn{5}{|l|}{ Any chronic illness } \\
\hline Yes & $30(6.2)$ & $24(8.6)$ & $6(2.9)$ & 0.012 \\
\hline No & $458(93.9)$ & $256(91.4)$ & 202(97.I) & \\
\hline
\end{tabular}

Table 6 A Multivariable Logistic Regression Showing Factors Associated with Herbal Medical Use

\begin{tabular}{|c|c|c|c|}
\hline Variable & $\begin{array}{l}\text { Adjusted Odds } \\
\text { Ratio }\end{array}$ & $95 \% \mathrm{Cl}$ & P-value \\
\hline \multicolumn{4}{|l|}{ Sex } \\
\hline Male & 1.59 & $1.11-2.33$ & 0.012 \\
\hline Female & 1.0 & - & \\
\hline \multicolumn{4}{|l|}{ Employment status } \\
\hline Employed & 1.64 & $1.15-2.38$ & 0.008 \\
\hline Not employed & 1.0 & - & \\
\hline \multicolumn{4}{|l|}{ Ever suffered of COVID-19 } \\
\hline Yes & 1.0 & & \\
\hline No & N/A & & \\
\hline \multicolumn{4}{|l|}{ Source of awareness } \\
\hline World Health Organization website & 1.0 & & \\
\hline Ministry of Health, Uganda & 0.92 & $0.55-1.56$ & 0.765 \\
\hline Other & 1.48 & $0.85-2.56$ & 0.163 \\
\hline \multicolumn{4}{|c|}{$\begin{array}{l}\text { Effect of these media messages on use of natural remedies } \\
(n=394)\end{array}$} \\
\hline I decreased the use & 2.66 & $1.24-5.72$ & 0.05 \\
\hline I increased the use & 1.65 & $1.01-1.65$ & 0.012 \\
\hline No effect & 1.0 & & \\
\hline \multicolumn{4}{|l|}{ Any chronic illness } \\
\hline Yes & 1.0 & & 0.290 \\
\hline No & 0.31 & $0.04-2.71$ & \\
\hline
\end{tabular}




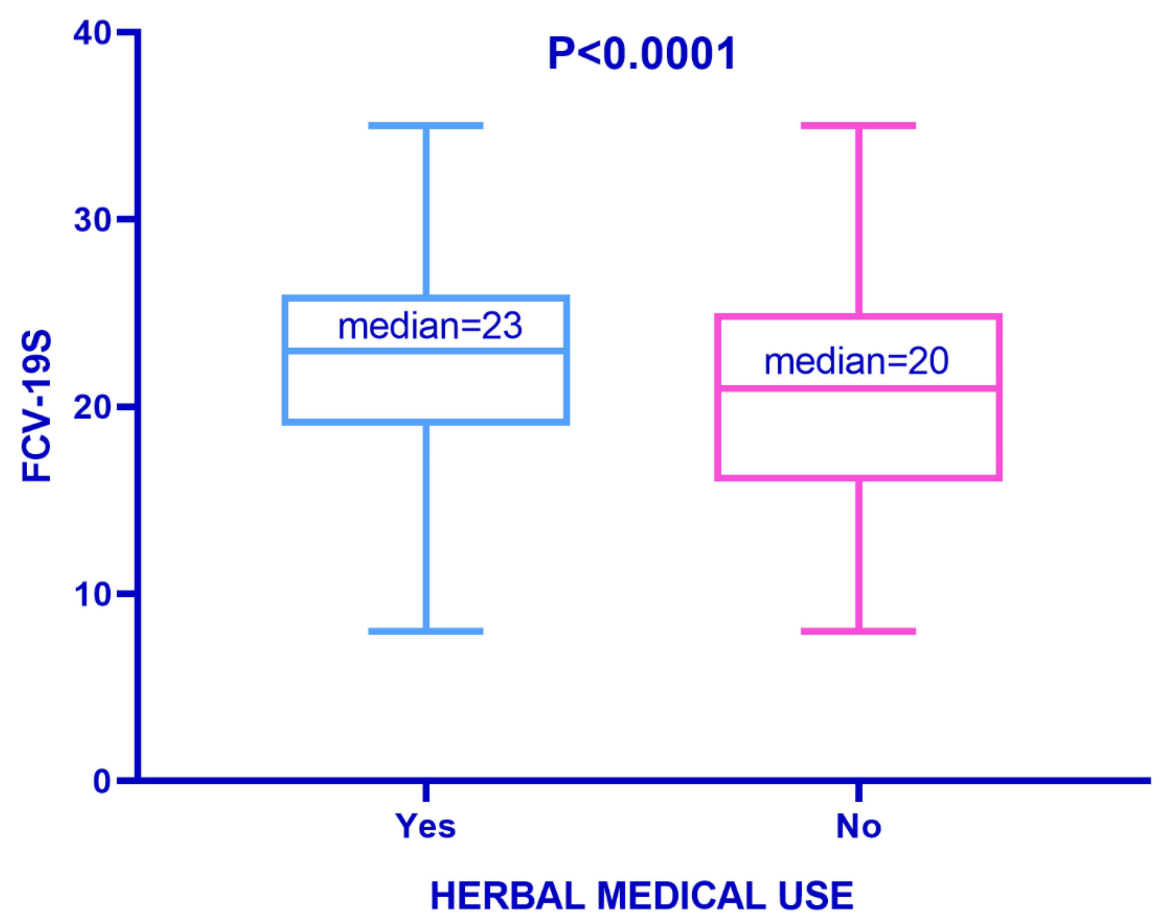

Figure 2 Fear of COVID-19 score stratified by herbal medicine use.

\section{Data Sharing Statement}

The data used to support the results of the research are available from the corresponding author upon request.

\section{Author Contributions}

All authors made substantial contributions to conception and design, acquisition of data, or analysis and interpretation of data, took part in drafting the article or revising it critically for important intellectual content, agreed to submit to the current journal, gave final approval to the version to be published, and agree to be accountable for all aspects of the work.

\section{Funding}

Research reported in this publication was supported by the Fogarty International Center of the National Institutes of Health, US Department of State's Office of the US Global AIDS Coordinator and Health Diplomacy (S/GAC), and President's Emergency Plan for AIDS Relief (PEPFAR) under Award Number 1R25TW011213. The content is solely the responsibility of the authors and does not necessarily represent the official views of the National Institutes of Health.

\section{Disclosure}

The authors declare no potential conflicts of interest in this work.

\section{References}

1. Worldometer. Coronavirus mortality rate (COVID-19) - worldometer; 2020. Available from: https://www.worldometers.info/. Accessed September 13, 2021.

2. Woo CSJ, Lau JSH, El-Nezami H. Herbal medicine: toxicity and recent trends in assessing their potential toxic effects. Adv Bot Res. 2012;62:365-384.

3. Kiconco A. Uganda national drug authority approves COVIDEX local herb medicine | Kampala International University, Uganda. KIU News; 2021 [cited September 6 2021]. Available from: https:// kiu.ac.ug/news-page.php?i=uganda-national-drug-authority-approves -covidex-local-herb-medicine. Accessed September 13, 2021.

4. Alyami HS, Orabi MAA, Aldhabbah FM, et al. Knowledge about COVID-19 and beliefs about and use of herbal products during the COVID-19 pandemic: a cross-sectional study in Saudi Arabia. Saudi Pharm J. 2020;28(11):1326-1332. doi:10.1016/j.jsps.2020.08.023

5. Ahmad AR, Murad HR. The impact of social media on panic during the COVID-19 pandemic in Iraqi Kurdistan: online questionnaire study. J Med Internet Res. 2020;22(5):e19556. doi:10.2196/19556

6. Saud M, Mashud M, Ida R. Usage of social media during the pandemic: seeking support and awareness about COVID-19 through social media platforms. J Public Aff. 2020;20(4):e2417.

7. de Hoog N, Stroebe W, de Wit JBF. The processing of fear-arousing communications: how biased processing leads to persuasion. Soc Influ. 2008;3(2):84-113.

8. Angus Reid Institute. Half of Canadians Taking Extra Precautions as Coronavirus Continues to Spread Around the Globe. Angus Reid Institute; 2020.

9. Gerhold L. COVID-19: Risk Perception and Coping Strategies. Results from a Survey in Germany. Interdisciplinary Security Research Group; 2020.

10. Aubrey A. Poll: Most Americans Say US “Doing Enough” to Prevent Coronavirus Spread. National Public Radio; 2020. 
11. Mamun MA, Griffiths MD. First COVID-19 suicide case in Bangladesh due to fear of COVID-19 and xenophobia: possible suicide prevention strategies. Asian J Psychiatr. 2020;51:102073. doi:10.1016/j.ajp.2020.102073

12. Goyal K, Chauhan P, Chhikara K, Gupta P, Singh MP. Fear of COVID 2019: first suicidal case in India! Asian J Psychiatr. 2020;49:101989. doi:10.1016/j.ajp.2020.101989

13. Şimşir Z, Koç H, Seki T, Griffiths MD. The relationship between fear of COVID-19 and mental health problems: a meta-analysis. Death Stud. 2021; 1-9. doi:10.1080/07481187.2021.1889097

14. Alotiby A. The impact of media on public health awareness concerning the use of natural remedies against the COVID-19 outbreak in Saudi Arabia. Int J Gen Med. 2021;14:3145-3152. doi:10.2147/ IJGM.S317348

15. Nguyen PH, De Tran V, Pham DT, Dao TNP, Dewey RS. Use of and attitudes towards herbal medicine during the COVID-19 pandemic: a cross-sectional study in Vietnam. Eur J Integr Med. 2021;44:101328. doi:10.1016/j.eujim.2021.101328

16. Abdullah Alotiby A, Naif Al-Harbi L. Prevalence of using herbs and natural products as a protective measure during the COVID-19 pandemic among the Saudi population: an online cross-sectional survey. Saudi Pharm J. 2021;29(5):410-417. doi:10.1016/j.jsps.2021.04.001

17. Reznik A, Gritsenko V, Konstantinov V, Khamenka N, Isralowitz R. COVID-19 fear in Eastern Europe: validation of the fear of COVID-19 scale. Int $J$ Ment Health Addict. 2020. doi:10.1007/ s11469-020-00283-3

18. Midorikawa H, Aiba M, Lebowitz A, et al. Confirming validity of the fear of COVID-19 scale in Japanese with a nationwide large scale sample. PLoS One. 2021;16(2):e0246840. doi:10.1371/journal. pone. 0246840

19. Huarcaya-Victoria J, Villarreal-Zegarra D, Podestà A, Luna-Cuadros MA. Psychometric properties of a Spanish version of the fear of COVID-19 scale in general population of Lima, Peru. Int $J$ Ment Health Addict. 2020. doi:10.1007/s11469-020-00354-5

20. Martínez-Lorca M, Martínez-Lorca A, Criado-álvarez JJ, Armesilla MDC, Latorre JM. The fear of COVID-19 scale: validation in Spanish university students. Psychiatry Res. 2020;293:113350. doi:10.1016/j.psychres.2020.113350

21. Mahmood QK, Jafree SR, Qureshi WA. The psychometric validation of FCV19S in Urdu and socio-demographic association with fear in the People of the Khyber Pakhtunkhwa (KPK) Province in Pakistan. Int J Ment Health Addict. 2020. doi:10.1007/s11469-020-00371-4
22. Perz CA, Lang BA, Harrington R. Validation of the fear of COVID-19 scale in a US college sample. Int J Ment Health Addict. 2020. doi:10.1007/s11469-020-00356-3

23. Fitzpatrick KM, Harris C, Drawve G. Fear of COVID-19 and the mental health consequences in America. Psychol Trauma Theory Res Pract Policy. 2020;12:S17-S21. doi:10.1037/tra0000924

24. Halser G. Pathophysiology of depression: do we have any solid evidence of interest to clinicians? World Psychiatry. 2010;9:155.

25. Andrade EF, Pereira LJ, de Oliveira APL, et al. Perceived fear of COVID-19 infection according to sex, age and occupational risk using the Brazilian version of the fear of COVID-19 scale. Death Stud. 2020;1-10. doi:10.1080/07481187.2020.1809786

26. Colizzi M, Bortoletto R, Silvestri M, et al. Medically unexplained symptoms in the times of COVID-19 pandemic: a case-report. Brain Behav Immun Health. 2020;5:100073.

27. Ornell F, Schuch JB, Sordi AO, Kessler FHP. "Pandemic fear" and COVID-19: mental health burden and strategies. Braz J Psychiatry. 2020;42:232-235. doi:10.1590/1516-4446-2020-0008

28. Heiat M, Heiat F, Halaji M, et al. Phobia and Fear of COVID-19: origins, complications and management, a narrative review. Ann Ig. 2021;33(4):360-370

29. Kwok KO, Li KK, Chan HHH, et al. Community responses during early phase of COVID-19 epidemic, Hong Kong. Emerg Infect Dis. 2020;26(7):1575-1579. doi:10.3201/eid2607.200500

30. Al-Rahimi JS, Nass NM, Hassoubah SA, Wazqar DY, Alamoudi SA, Menezes RG. Levels and predictors of fear and health anxiety during the current outbreak of COVID-19 in immunocompromised and chronic disease patients in Saudi Arabia: a cross-sectional correlational study. PLoS One. 2021;16(4):e0250554. doi:10.1371/journal. pone. 0250554

31. Bing. Health seeking behaviour and challenges in utilising health facilities in Wakiso district, Uganda; [cited August 1, 2021]. Available from: https://www.bing.com/search?q=Health+seeking + behaviour+and + challenges + in + utilising + health + facilities + in +Wakiso+district $\% 2 \mathrm{C}+$ Uganda\&cvid=00a8bebc10a94d 1 faf5d 8 b6d d3e40ccb\&aqs=edge.69i57.567j0j9\&FORM=ANAB01\&PC=U531. Accessed September 13, 2021.
Risk Management and Healthcare Policy

\section{Publish your work in this journal}

Risk Management and Healthcare Policy is an international, peerreviewed, open access journal focusing on all aspects of public health, policy, and preventative measures to promote good health and improve morbidity and mortality in the population. The journal welcomes submitted papers covering original research, basic science, clinical \& epidemiological studies, reviews and evaluations, guidelines, expert opinion and commentary, case reports and extended reports. The manuscript management system is completely online and includes a very quick and fair peer-review system, which is all easy to use. Visit http://www.dovepress.com/testimonials.php to read real quotes from published authors. 